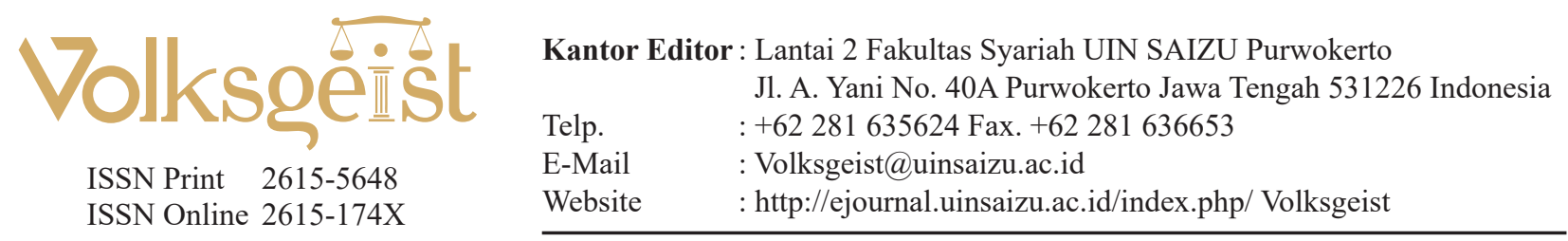

\title{
Kebijakan Moderasi Pidana Mati dalam RUU KUHP Perspektif Nilai-Nilai Pancasila
}

\author{
Sugeng Riyadi ${ }^{1}$, Beny Timor Prasetyo ${ }^{2}$ \\ ${ }^{1}$ Program Doktor Ilmu Hukum Universitas Jenderal Soedirman, Dosen Ilmu Hukum Universitas \\ Nahdlatul Ulama Purwokerto \\ ${ }^{2}$ Program Doktor Ilmu Hukum Universitas Jenderal Soedirman \\ ${ }^{1}$ Email: adv.sugengriyadi@gmail.com
}

\begin{abstract}
Abstrak
Penelitian ini bertujuan menjawab apakah kebijakan pidana mati dalam RUU KUHP sesuai dengan nilai-nilai Pancasila ataukah tidak. Penggunaan Pancasila sebagai batu uji karena merupakan cita hukum dan sekaligus Norma Fundamental Negara Republik Indonesia. Setiap norma yang ada harus bersumber dari norma di atasnya sampai akhirnya berhenti pada norma fundamental negara. Jika ada norma yang tidak bersumber dari norma diatasnya maka norma tersebut dikatakan invalid. Penelitian ini termasuk penelitian doktrinal dengan pendekatan perundang-undangan, pendekatan konsep dan pendekatan filosofis. Hasil penelitian menunjukan bahwa kebijakan pidana mati yang terdapat dalam RUU KUHP tidak bertentangan dengan nilai-nilai Pancasila. Dasar kebijakannya guna menyalurkan hasrat balas dendam masyarakat melalui jalur hukum, menghindari extra legal execution, mencari keadilan, dan menimbulkan efek jera dan sebagai upaya perlindungan terhadap "hak hidup" orang orang banyak. Semua itu sejalan dengan nilai-nilai Pancasila.
\end{abstract}

Kata Kunci: RUU KUHP; nilai-nilai pancasila; pidana mati

\begin{abstract}
This study aims to answer whether or not the death penalty policy in the Draft of the Criminal Code is in accordance with the values of Pancasila. The use of Pancasila as a touchstone because it is a legal ideal and at the same time the Fundamental Norms of the Republic of Indonesia. Every existing norm must be sourced from the norms above it until it finally stops at the state's fundamental norms. If there is a norm that does not originate from the above norm, then the norm is said to be invalid. This research includes doctrinal research with a statutory approach, a conceptual approach and a philosophical approach. The results of the study show that the death penalty policy contained in the Draft of the Criminal Code does not conflict with the values of Pancasila. The basis of the policy is to channel the public's desire for revenge through legal channels; avoid extra legal executions; seek justice; create a deterrent effect; and as an effort to protect the right to life of many people. All of this is in line with the values of Pancasila.
\end{abstract}

Keywords: Draft criminal code; values of pancasila; death penalty. 


\section{Sejarah Artikel}

Dikirim: 07 September 2021

Direview: 10 November 2021

Diterima: 19 November 2021

Diterbitkan: 01 Desember 2021

\section{PENDAHULUAN}

Pembaharuan hukum pidana melalui modernisasi dan rekodifikasi hukum pidana adalah agenda lama yang sudah dicanangkan Pemerintah Indonesia. RUU KUHP mulai disusun sejak 1963 dan sampai sekarang belum selesai pembahasannya ${ }^{1}$. Tahun 2019 Pemerintah dan DPR hampir menyepakati rancangan tersebut namun akhirnya gagal karena masih banyak penolakan dari masyarakat. Banyak hal pokok yang dibahas dalam RUU KUHP salah satunya soal pidana mati. RUU KUHP masih memberikan tempat pada pidana mati sebagai salah satu sanksi pidana. Sekalipun kedudukananya bukan lagi sebagai pidana pokok tetapi hanya sebagai pidana khusus dan diancamkan secara alternative, namun esensinya pidana mati masih tetap eksis di ius contituendum kita.

Pidana mati pernah diuji konstitusionalitasnya oleh Mahkamah Konstitusi ${ }^{2}$. Menurut Mahkamah Konstitusi Pidana Mati dinilai konstitusional. Sekalipun sudah ada putusan konsitusionalitas pidana mati bukan berarti polemiknya lenyap. Polemik ini selalu hidup kembali terutama ketika ada momen putusan pidana mati, eksekusi pidana mati, atau ada permohonan grasi terpidana mati. Pro-Kontra pidana mati merupakan perdebatan abadi. Dalam tingkat global pidana mati juga isu yang selalu hidup. Pro Kontra Pidana mati

\footnotetext{
1 Benhard Ruben Fritz Sumigar, 'Pelangaran Berat HAM Dalam RUU KUHP: Tinjauan Dari Hukum Internasional' Vol 11 No. 2 November 2020. (n.d.).

2 'Putusan Mahkamah Konstitusi No. 2-3/ PUU-v/2007', oktober 2007.
}

dipengaruhi oleh idiologi, politik dan budaya ${ }^{3}$.

Perdebatan tentang Pidana Mati berkisar pada soal perlindungan masyarakat, sistem penyelenggaraan hukum pidana, deterent, sifat diskriminatif, sifat kejamnya pidana mati, biaya yang lebih murah, sifat re tributive, opini masyarakat tentang pro-kontra pidana mati, sifat tidak dapat diubah pidana mati ${ }^{4}$.

Sekalipun RUU KUHP dan KUHP samamasa mencantumkan Pidana Mati sebagai salah satu jenis pidananya namun pemikiran yang melatarbelakanginya berbeda. Dasar pemikiran dibalik Pidana Mati didalam KUHP lebih karena alasan kolonialisme. Pemerintah kolonial waktu itu ingin menjaga daerah kekuasaannya yang sangat luas, sementara aparat kepolisian dan aparat keamanan sangat terbatas jumlahnya sehingga pemerintah kolonial kedodoran, untuk itu diperlukan hukuman mati untuk tindak pidana-tindak pidana tertentu yang mempunyai sifat menakut-nakuti masyarakat ${ }^{5}$. Di Negeri Belanda sendiri Pidana Mati untuk golongan sipil sudah dihapuskan sejak tahun $1870^{6}$.

Sedangkan Pidana Mati dalam RUU KUHP didasarkan pada pemikiran untuk menyalurkan hasrat balas dendam masyarakat melalui jalur hukum, menghindari extra legal execution, mencari keadilan, dan menimbulkan efek jera? ${ }^{7}$

3 Saharuddin Daming, 'Konfigurasi Pertarungan Abolisinisme Versus Retensionisme Dalam Diskursus Keberadaan Lembaga Pidana Mati Di Tingkat Global Dan Nasional', n.d.

4 'Draff Naskah Akademik RUU KUHP Pasal 100 (4)' (n.d.).

5 JE Sahetapy, 'Pidana Mati Dalam Negara Pancasila, Citra Aditya Bandung 2007 Hal 73; Lihat Juga Lidya Suryani Widayati, Pidana Mati Dalam RUU KUHP: Perlukan Diatur Sebagai Pidana Yang Bersifat Khusus? Jurnal Negara Hukum: Vol. 7 No. 2 November 2016. Hal 168', n.d.

6 Andi Hamzah, Pidana Mati Di Indonesia Di Masa Lalu, Kini Dan Di Masa Depan (Ghalia Indoesia, 1985), 32.

7 I Nyoman Alit Putrawan, I Gusti Ngurah Sudiana, and I Nyoman Sirta, 'Paradara Dalam Delik Kesusilaan Di Kota Denpasar Perspektif Hukum Hindu', Jurnal Penelitian Agama Hindu Volume 3 Nomer 1 tahun 
Disamping itu pidana mati juga dipandang sebagai upaya perlindungan terhadap "hak hidup" dari banyak orang.

Penempatan Pidana Mati dalam RUU KUHP telah melewati perdebatan panjang. Kelompok yang pro (retensionis) berargument sebagaimana disebutkan diatas. Sedangkan kelompok yang kontra (abolisionis) berpendapat Pidana Mati melanggar HAM, tidak menimbulkan efek jera, sangat kejam dan tidak manusiawi serta hukum peninggalan pemerintah kolonial yang tidak cocok lagi dengan nilai-nilai yang ada dimasyarakat. Disamping itu ada kekhawatiran pula tentang kesalahan dalam proses pidana yang sudah tidak bisa ditinjau lagi, dan banyaknya negara yang telah meninggalkan hukuman mati ${ }^{8}$.

Dari tarik menarik dua pendapat tersebut akhirnya Tim Penyusun RUU KUHP mencapai kesepakatan dengan mempertahankan pidana mati namun dengan moderasi (pelunakan). Moderasi kebijakan pidana mati merupakan bentuk kompromi dari kelompok retensionis dan kelompok abolisionis ${ }^{9}$.

Selanjutnya apakah kebijakan mempertahanakan kebijakan pidana dengan moderasi dalam RUU KUHP telah sesuai dengan pancasila atau belum. Penggunaan Pancasila sebagai batu uji karena ia merupakan cita hukum (rechtsidee) dan sekaligus sebagai Norma Fundamental Negara Indonesia ${ }^{10}$.

Sebagai cita hukum, Pancasila dijadikan leitstarataubintang pemandubagipembangunan

2019 (n.d.): 229-43.

8 Lidya Suryani Widayati, 'Pidana Mati Dalam RUU KUHP: Perlukan Diatur Sebagai Pidana Yang Bersifat Khusus? Jurnal Negara Hukum' Vol. 7 No. 2 November 2016. (n.d.): 168.

9 'NA RUU KUHP' (n.d.).

${ }^{10}$ A. Hamid s Attamimi, Pancasila Cita Hukum Dalam Kehidupan Hukum Bangsa Indonesia, Dalam Moerdiono Dkk, Pancasila Sebagai Ideologi Dalam Berbagai Bidang Kehidupan Bermasyarakat, Berbangsa Dan Bernegara, Disunting Oleh Oetojo Oesman Dan Alfian (BP-7 Pusat, 1992), 62-88. hukum di Indonesia. Dalam kedudukannya yang demikian Pancasila dipandang berada diluar Sistem Norma Hukum. Menurut Gustav Radbruch cita hukum mempunyai dua fungsi yaitu fungsi konstitutif dan regulatif. Fungsi konstitutif artinya cita hukum menentukan dasar suatu tata hukum, yang tanpa itu tata hukum kehilangan arti dan maknanya secara hukum. Fungsi regulatif artinya cita hukum menjadi batu uji apakah hukum positif yang berlaku ini hukum yang adil atau tidak ${ }^{11}$.

Sebagai Norma Fundamental Negara Pancasila posisinya berada dalam puncak piramida Sistem Norma Hukum dalam negara. Sehingga menjadi sumber berlakunya peraturanperaturan di bawahnya. Sebagai Norma tertinggi maka diasumsikan sudah ditetapkan terlebih dahulu ${ }^{12}$. Pancasila sendiri menurut Soekarno itu sudah hidup selama berabad-abad lamanya di bumi pertiwi. Para founding father hanya memunculkan saja dan menyepakati ini sebagai dasar negara Indonesia.

Dengan mengikuti pembagian jenjang norma dan pengelompokan norma dari Hans Nawiaski maka secara berturut-turut dari atas kebawah adalah staats fundamental norm (Norma Fundamental Negara), Staats grund gesetz (Aturan Dasar Negara), Formell Gesetz (undang-undang Formal) dan Verordnung \& Autonome Satzung (aturan pelaksana \& Aturan otonom)

Pada konteknya, di Indonesia RUU KUHP berada dalam posisi Formell Gesetz dan Pancasila sendiri berada dalam posisi staats fundamental lnorm. Dengan demikian RUU KUHP berdasarkan pada UUD 1945, dan UUD 1945 mendasakarkan pada Pancasila. Soekarno berpendapat bahwa Pancasila adalah dasar atau Philosofische grondslag, atau Weltanschuung

\footnotetext{
${ }^{11}$ A. Hamid s Attamimi, 62-68.

${ }^{12}$ A.Hamid S. Attamimi, Gesetz Gebung Swissens Chaft Sebagai Salah Satu Upaya Menanggulangi Hutan Belantara Peraturan Perundang-Undangan (Depok: Badan Penerbit FH UI, 2021), 219.
} 
dari pada negara Indonesia. Tidak hanya itu menurutnya Pancasila juga merupakan alat pemersatu bangsa ${ }^{13}$. Selain daripada itu Moh. Mahfud MD mengatakan bahwa Pancasila juga dapat dipahami sebagai paradigma politik hukum dan platform kehidupan bersama bagi bangsa Indonesia ${ }^{14}$.

Penelitian tentang Pidana Mati di Indonesia telah banyak dilakukan oleh peneliti, namun penelitian yang mengkaji kebijakan moderasi pidana mati di RUU KUHP dari perspektif nilai-nilai pancasila belum dilakukan. Berikut ini beberapa penelitian dengan topik pidana mati dan perbedaannya dengan fokus kajian.

Pertama, Penelitian dengan judul "Politik Kebijakan Hukuman Mati Di Indonesia Dari Masa Ke Masa", oleh Tim Institute for Criminal Justice Reform. Penelitian ini mengkaji latar belakang dan dinamika sosial politik kebijakan pemidanaan hukuman mati sebagai sanksi pidana dalam peraturan perundang-undangan di Indonesia; dan kesesuaian kebijakan hukuman mati di Indonesia dengan prinsip dan norma Universal $\mathrm{HAM}^{15}$. Penelitian ini menunjukkan bahwa kebijakan menggunakan pidana mati sebagai sarana hukum dengan alasan yang berbeda-beda. Pada Masa kolonialisme alasananya untuk membungkam perlawanan orang pribumi, sementara pada masa revolusi fisik dalam kontek hukum militer alasannya untuk memperkuat strategi mempertahankan kemerdekaan, pada masa demokrasi liberal untuk memberangus para pemberontak, pada masa demokrasi terpimpin alasanya untuk menjaga stabilitas nasional dalam rangka mengamankan revolusi, pada masa orde baru alasannya untuk stabilitas politik dan pada masa

${ }^{13}$ Soekarno, 'Pantja Sila Sebagai Dasar Negara, Departemen Penerangan RI 1959.' (n.d.).

${ }^{14}$ Moh Mahfud MD, Membangun Politik Hukum, Menegakkan Konstitusi (Jakarta: LP3ES, 2006), 30-31.

15 Tim Institute For Criminal Justice Reform (ICJR), Politik Kebijakan Hukuman Mati Di Indonesia Dari Masa Ke Masa (Jakarta, n.d.), 240-41. sekarang untuk kedaruratan ${ }^{16}$. Instrument HAM memang masih membolehkan hukuman mati namun hanya untuk kasus-kasus berkategori the most serious crime, sementara itu di Indonesia hal tersebut dicampuradukan dengan istilah kejahatan-kajahatan yang memerlukan penanganan yang luar biasa, untuk itu perlu dikaji ulang ${ }^{17}$.

Kedua, Penelitian berjudul: "Eksistensi Pidana Mati dalam Pembaharuan Hukum Pidana (Kajian Terhadap Pidana Mati Dalam RUU KUHP)" yang ditulis oleh Tia Ludiana ${ }^{18}$. Dalam penelitian tersebut fokusnya tentang analisis perkembangan pidana mati di Indonesia, analisis pidana mati di KUHP dan didalam RUU KUHP. Penelitian ini menunjukan bahwa hukuman mati adalah hukum pokok yang utama di KUHP dan saat ini masih tetap dipertahankan, sedangan dalam RUU KUHP hukuman mati masih dipertahankan namun sebagai sarana terkahir.

Ketiga, Penelitian berjudul: "Hukuman Mati Ditinjau Dari Perspektif Hukum dan Hak Asasi Manusia Internasional" oleh Ayub Torry Satrio Kusumo ${ }^{19}$. Penelitian ini berfokus pada kebijakan formulasi hukuman mati dalam hukum positif di Indonesia, dan penerapan hukuman mati ditinjau menurut hukum hak asasi manusia. Hasil dari penelitian tersebut menunjukan bahwa hukuman mati masih diterapkan di Indonesia dan masih tercantum sebagai hukum Pokok sebagaimana tertuang dalam Pasal 10 KUHP. Hukuman mati bertentangan dengan Pasal 3 DUHAM,

16 Tim Institute For Criminal Justice Reform (ICJR), 240-41.

17 Tim Institute For Criminal Justice Reform (ICJR), 241.

${ }^{18}$ Tia Ludiana, 'Eksistensi Pidana Mati Dalam Pembaharuan Hukum Pidana (Kajian Terhadap Pidana Mati Dalam RUU KUHP)', Jurnal Litigasi (e-Journal) Vol. 22 (1) (April 2020): 60-79.

${ }^{19}$ Ayub Torry Satriyo Kusumo, 'Hukuman Mati Ditinjau Dari Perspektif Hukum Dan Hak Asasi Manusia Internasional', n.d., Koleski Pusat Dokumentasi ELSAM. 
namun ada pengecualian dalam pelaksanaanya sebagaimana diatur dalam Pasal 4 ayat (1) ICCPR.

Keempat, Penelitian berjudul: "Konstitusionalitas Hukuman Mati di Indonesia dalam perspektif Hukum Islam dan Hak Asasi Manusia" ditulis oleh Budi Ruhiatudian. Fokus kajian penelitian ini adalah: konsepsi pidana mati yang berlaku di Indonesia dan nilai-nilai filosofis dari hukuman mati di Indonesia yang dikaitkan dengan nilai-nilai HAM PBB dan hukum Islam ${ }^{20}$. Penelitian ini menujukan bahwa hukuman mati adalah hukuman yang terberat. Hukuman mati tidak dapat dinilai melanggar HAM. Hukuman mati diakui oleh Hukum Islam tujuannya demi menjaga hidup dan kehidupan.

Kelima, Penelitian berjudul: Kebijakan Pidana Mati dalam RKUHP Ditinjau Dari Aspek Politik Hukum Dan HAM" ditulis oleh Aji Ramdan $\mathrm{dkk}^{21}$. Tujuan penelitian ini: apakah model kebijakan pidana mati dalam RKUHP tepat apabila ditinjau dari aspek politik hukum nasional. Dan model kebijakan pidana mati dalam RKUHP ditinjau dari aspek HAM ${ }^{22}$. Hasil penelitian ini menunjukan bahwa kebijakan pidana mati telah sesuai dengan politik hukum tetap dan temporer. Model kebijakan pidana mati di dalam RUU KUHP tidak bertentangan dengan HAM dan sudah selaras dengan pandangan HAM yang dianut dalam UUD 1945.

Keenam, penelitian oleh Roby Anugerah dan Raja Desril, dengan judul: Kebijakan Formulasi Pidana Mati dalam Pembaharuan Hukum Pidana Indonesia. ${ }^{23}$. Penelitian ini

${ }^{20}$ Tia Ludiana, 'Eksistensi Pidana Mati Dalam Pembaharuan Hukum Pidana (Kajian Terhadap Pidana Mati Dalam RUU KUHP)'.

${ }^{21}$ Ajie Ramdan, Rully Herdita Ramadhani, and Mei Susanto, 'Kebijakan Pidana Mati Dalam RKUHP Ditinjau Dari Aspek Politik Hukum Dan HAM', Arena Hukum 11 Nomor 3 (Desember 2018): 600-617.

${ }^{22}$ Ajie Ramdan, Rully Herdita Ramadhani, and Mei Susanto, 600-617.

${ }^{23}$ Roby Anugerah and raja Desril, 'Kebijakan mengkaji lebih tentang kebijakan formulasi pidana mati dalam pembahauan hukum pidana Indonesia. Hasil penelitian ini menunjukkan bahwa pidana mati sebagai pidana khusus dan digunakan sebagai upaya terakhir dalam mengayomi masyarakat, pidana mati juga dapat dirubah menjadi hukuman penjara seumur hidup setelah terpidana merasa menyesal dan mau memperbaiki diri selama masa percobaan.

Dari penelitian yang sudah penulis telaah, belum ada penelitian yang fokus terhadap Kebijakan Moderasi Pidana Mati di RUU KUHP ditinjau nilai-nilai Pancasila. Penelitian ini merupakan penilitian hukum. Menurut Marzuki, Peneltian hukum adalah sutu proses menemukan aturan hukum, prinsip-prinsip hukum, maupun doktrin-dokterin hukum untuk menjawab pertanyaan-pertanyaan hukum yang diajukan $^{24}$.

Bertolak dari pemahaman di atas, tulisan ini termasuk dalam penelitian hukum guna mencari jawaban dasar pembenaran kebijakan moderasi pidana mati dari perspektif Pancasila. Pancasila disini baik dalam kedudukannya sebagai Cita Hukum maupun sebagai Norma Fundamental Negara Kesatuan Republik Indonesia. Pendekatan yang digunakan penulis adalah pendekatan doktrinal yang bersifat kualitataif dan berdasar pada data sekunder.

Jenis penelitian yang digunakan adalah penelitian pustaka. Jenis penelitian ini datanya adalah dokumen tertulis. Sumber data yang digunakan mencakup bahan hukum primer maupun sekunder. Pendekatan yang digunakan dalam tulisan ini adalah pendekatan perundangundangan, pendekatan konsep dan pendekatan filosofis. Pendekatan perundangan-undangan dimaksudkan untuk meneliti peraturan

Formulasi Pidana Mati Dalam Pembaharuan Hukum Pidana Indonesia, Jurnal Pembangunan Hukum Indonesia', Jurnal Pembangunan Hukum Indonesia Volume 3 No 1 tahun 2021 (n.d.): 80-95.

${ }^{24}$ Peter Mahmud Marzuki, Penelitian Hukum (Jakarta: Kencana Prenanda Media Group, 2005). 
perundangan-undangan terkait kebijakan moderasi pidana mati pada ius contsituendum. Pendekatan konsep dimaksudkan untuk memahami konsep kebijakan pidana mati didalam RUU KUHP. Sedangakn pendekatan filosofis digunakan untuk menganalisis kebijakan moderasi kebijakan pidana mati dari perspektif Pancasila selaku idiologi, falsafah, cita hukum dan juga sebagai norma dasar Negara Kesatuan Republik Indonesia.

Tujuan penelitian ini adalah untuk mendapatkan jawaban apakah kebijakan moderasi pidana mati dalam RUU KUHP tersebut mendapatkan dasar pembenarannya dari Pancasila. Lebih lanjut tulisan ini diharapkan berguna memperkaya pemikiran kebijakan moderasi pidana mati di RUU KUHP dari sudut pandang Pancasila.

\section{PEMBAHASAN}

\section{Politik Hukum Pidana Mati}

Mempertahankan pidana mati dengan moderasi dalam ius constituendum merupakan pilihan politik hukum bangsa Indonesia. Menurut Soehino politik hukum merupakan proses pembentukan hukum ius constituendum dari ius constitutum dalam rangka menghadapai perubahan kehidupan bermasyarakat ${ }^{25}$. Sejalan dengan itu Padmo Wahyono mengatakan politik hukum merupakan kebijakan penyelenggaraan negara yang bersifat mendasar dalam menentukan arah, bentuk maupun isi dari hukum yang akan dibentuk ${ }^{26}$.

Dalam menentukan arah tersebut kita harus berpegang pada nilai-nilai falsafah dan dasar negara. Falsafah negara merupakan norma dasar dalam penyelenggaran negara sehingga ia dapat dijadikan dasar pengujian apakah kebijakan-kebijakan negara sesuai dengan

25 Soehino, Politik Hukum Di Indonesia (Yogyakarta: Penerbit BPFE, 2010), 3.

26 Padmo wahyono, Indonesia Berdasar Atas Hukum (Ghalia Indonesia, n.d.), 160. persetujuan masyarakat atau $\operatorname{tidak}^{27}$. Secara teoritis nilai merupakan pemahaman yang berasal dari hasil perenungan yang mendalam yang dianggap paling benar, bijaksana dan baik $^{28}$. Nilai dijadikan sebagai landasan, alasan, atau motivasi bagi manusia. Dalam mengadakan penilaian terhadap sesuatu yang bersifat rohaniah manusia menggunakan hati nuraninya dengan dibantu inderanya, akalnya, kehendaknya, dan juga oleh keyakinannya. Sesuatu dikatakan mempunyai nilai apabila sesuatu itu berguna, benar, indah, baik dan religious $^{29}$.

Pancasila merupakan idiologi terbuka bagi Negara Indonesia karena ia digali dari kekayaan rohani, moral dan budaya masyarakat Indonesia sendiri dan bukan dari luar ${ }^{30}$. Dari penggalian tersebut oleh para pendiri Negara Indonesia Pancasila dirumuskan menjadi dasardasar bernegara sebagaimana yang termaktub dalam pembukaan UUD 45 yang terdiri dari Ketuhanan Yang Esa, Kemanusiaan yang adil dan beradab, Persatuan Indonesia, Kerakyatan yang dipimpin oleh hikmah kebijksanaan dalam Permusyawaratan/ perwakilan, dan Keadilan bagi seluruh rakyat Indonesia. Dari Perumusan tersebut Pancasila ditempatkan dalam dua posisi baik sebagai cita hukum dan sekaligus sebagai Norma Dasar dari Negara Kesatuan Republik Indonesia.

Teori yang digunakan dalam tulisan ini ada dua, yaitu teori tujuan pemidanaan dan teori jenjang norma hukum (stufentheorie). Pidana mati sebagai salah satu jenis hukuman yang ada di dalam RUU KUHP tentu mempunyai tujuan. Sementara itu dalam teori jenjang norma, setiap norma hukum dapat dikenali

${ }^{27}$ Franz Magnis Suseno, Etika Politik PrinsipaPrinsip Moral Dasar Kenegaraan Modern (Jakarta: Gramedia Pustaka Utama, 2001), 372.

${ }^{28}$ Darji Darmodiharjo and dkk, Santiaji Pancasila (Surabaya: Usaha Nasional, 1991), 50-53.

${ }^{29}$ Darji Darmodiharjo and dkk, 50-53.

${ }^{30}$ Franz Magnis Suseno, Etika Politik PrinsipaPrinsip Moral Dasar Kenegaraan Modern, 371. 
dari mana datangnya norma tersebut ${ }^{31}$. Sebab setiap norma akan selalu bersumber dari norma diatasnya secara berjenjang dan terkahir sampai kepada norma dasar. Diatasnya norma dasar sudah tidak ada norma lagi. Demikian juga norma hukum Pidana Mati dapat ditelusuri ke atas sampai pada norma dasar negara kita Pancasila.

\section{Tujuan Pemidanaan}

Secara umum dalam khasanah ilmu hukum pidana terdapat tiga teori tujuan pemidanaan yaitu teori pembalasan, teori relatieve, dan teori gabungan. Dalam teori pembalasan yang dijadikan dasar pemikiran dari pidana adalah pembalasan. Teori ini dikenal pada akhir abad ke 18 dengan tokohnya Immanuel Kant, Hegel, Herbert dan Stahl. Dalam hal ini, aliran pembalasan dibedakan atas corak subyektif yang pembalasannya ditujukan pada kesalahan si pembuat karena tercela dan corak obyektif yang pembalasannya ditujukan sekedar pada perbuatan yang telah dilakukan orang tersebut ${ }^{32}$.

Sedangkan dasar pemikiran dari teori relatieve adalah terletak pada tujuan pidana itu sendiri. Cara mencapai tujuan, ada beberapa faham yang merupakan aliran dalam teori relatief ini yaitu:

Pertama, Prevensi Umum, dalam teori prevensi umum ini yang hendak dicapai adalah mencegah khalayak ramai untuk tidak melakukan tindak pidana serupa. Pidana dilakukan didepan umum agar menakutkan. Kedua, Prevensi Khusus, dalam teori ini tujuan pidana adalah untuk mencegah pelaku untuk melakukan tindak pidana lagi. Ketiga,

${ }^{31}$ A. Hamid s Attamimi, Pancasila Cita Hukum Dalam Kehidupan Hukum Bangsa Indonesia, Dalam Moerdiono Dkk, Pancasila Sebagai Ideologi Dalam Berbagai Bidang Kehidupan Bermasyarakat, Berbangsa Dan Bernegara, Disunting Oleh Oetojo Oesman Dan Alfian.

${ }^{32}$ Bambang Poernomo, Asas-Asas Hukum Pidana (Jakarta: Ghalia Indonesia, 1993), 27.
Memperbaiki si pembuat, menurut teori ini tujuan dari pidana adalah untuk memperbaiki si penjahat agar menjadi orang yang baik. Keempat, Menyingkirkan Penjahat, menurut teori ini apabila tujuan-tujuan sebagaimana disebutkan diatas tidak mungkin dapat dicapai maka tujuan selanjutnya adalah menyingkirkan si penjahat tersebut dengan cara dijatuhi hukum pidana mati atau penjara seumur hidup. Kelima, perbaikan masyarakat, menurut teori ini tujuan dari pidana adalah memperbaiki kerugian masyarakat yang sudah terjadi di masa lampau. Selanjutnya teori gabungan. Teori gabungan mendasarkan pada pemikiran bahwa pidana hendaknya didasarkan pada tujuan pembalasan dan sekaligus mempertahankan ketertiban masyarakat yang diterapkan secara kombinasi dengan menitikberatkan salah satu tanpa menghilangkan unsur yang lain ${ }^{33}$.

Tujuan Pemidanaan di RUU KUHP diatur didalam Pasal 51 menyebutkan:

a. Mencegah dilakukannya Tindak Pidana dengan menegakan norma hukum demi perlindungan dan pengayoman masyarakat;

b. Memasyarakatkan terpidana dengan mengadakan pembinaan dan pembimbingan agar menjadi orang yang baik dan berguna

c. Menyelesaikan konflik yang ditimbulkan akibat Tindak Pidana; memulihkan keseimbangan, serta mendatangkan rasa aman damai dalam masyarakat

d. Menumbuhkan rasa penyesalan dan membebaskan rasa bersalah pada terpidana.

Sebagaimana dijelaskan dalam Draft Naskah Akademik RUU KUHP 2015-2019 bahwa perumusan tujuan pemidanaan bertolak dari pemikiran bahwa pidana adalah alat untuk mencapai tujuan ${ }^{34}$. Tujuan pemidanaan sendiri sebagaimana dalam rumusan Pasal

\footnotetext{
${ }^{33}$ Bambang Poernomo, 27.

34 'Draff Naskah Akademik RUU KUHP Pasal
} 100 (4)', 35-36. 
51 tersebut serta penjelasan dari NA RUU KUHP bertolak dari keseimbangan dua sasaran pokok yaitu perlindungan masyarakat dan juga memperbaiki pelaku. Berpangkal pada pemikiran keseimbangan tersebut, maka syarat dan hakikat pemidanaan juga bertumpu pada keseimbangan monodualistik, yaitu antara kepentingan masyarakat dan kepentingan individu, antara faktor obyektif dan faktor subyektif.

Sehubungan dengan itu maka syarat pemidanaan berdasar pada asas legalitas dan asas culpabilitas. Dengan kata lain dua asas ini berhubungan erat dengan dua konsep dasar dalam hukum pidana yaitu tindak pidana dan pertanggungjawaban pidana.

Bergesernya pidana mati dari stelsel pidana pokok menjadi pidana khusus atau perkecualian itu didasarkan pada pemikiran bahwa memang pidana mati bukanlah sarana utama untuk mengatur, menertibkan dan memperbaiki masyarakat melainkan sebagai sarana pamungkas jika sarana lain sudah tidak dapat diandalkan. Penggunaan pidana mati diibaratkan amputansi dalam dunia kedokteran yaitu digunakan setelah sarana lain tidak dapat digunakan.

NA RUU KUHP menggariskan bahwa walaupun pidana mati lebih didasarkan pada perlindungan masyarakat namun dalam pelaksanaannya hendaknya berhati-hati dan berorientasi terhadap pelaku tindak pidana itu sendiri, sehingga harus selektif, dan perlu adanya ketentuan penundaan pelaksanaan pidana mati atau pidana mati bersyarat.

RUU KUHP menentukan bahwa Pidana Mati diancamkan secara alternative sebagai upaya terakhir mangayomi masyarakat. Pidana mati dapat dilaksanakan setelah grasinya ditolak. Pelaksanaan Pidana Mati terhadap wanita hamil, menyusui dan orang yang kena sakit jiwa ditunda sampai melahirkan, masa menyusuinya selesai dan orang yang sakit jiwa sembuh. Hakim dapat menjatuhkan Pidana Mati dengan masa percobaan selama 10 tahun dengan syarat-syarat: terdakwa menyesal dan dapat diperbaiki lagi; peran terdakwa tidak terlalu penting; dan ada alasan pemaaf. Jika dalam masa percobaan terpidana menujukan sikap dan perbuatan yang terpuji maka pidana mati dapat diubah dengan pidana sumur hidup dengan Keputusan Presiden setelah mendapat pertimbangan Mahkamah Agung ${ }^{35}$.

\section{Stuffentheorie}

Dalam teori Stuffentheorie. setiap sistem norma hukum selalu berjenjang-jenjang dan berkelompok-kelompok. Tidak ada norma hukum yang berdiri sendiri tanpa ada persambungannya dengan norma diatasnya. Sehingga setiap norma hukum dapat dilacak ke sumber norma diatasnya sampai berakhir ke norma dasar atau disebut sebagai Grundnorm. Dan dalam konteks Negara Kesatuan Republik Indonesia Grundnorm tersebut tidak lain adalah Pancasila. Maka dalam sistem norma hukum di Indonesia Pancasila merupakan Norma Fundamental yang diatasnya lagi sudah tidak ada norma lagi. Ia akan menjadi pegangan atau sumber terkahir dari sistem norma yang ada di Indonesia termasuk norma hukum pidana mati. Norma Hukum Pidana mati dapat dilacak dari undang-undang, undang-undang dasar sampai berpuncak pada Grundnorm.

\section{Sebaran Ketentuan yang Mencantumkan Pidana Mati dalam RUU KUHP}

Setelah mempelajari teori tujuan pemidanaan dan mempelajari teori jenjang norma hukum selanjutnya tulisan ini akan meninjau perbuatan apa saja yang oleh perumus diberikan ancaman hukuman pidana mati di RUU KUHP. Secara keseluruhan terdapat 10

35 'Draff Naskah Akademik RUU KUHP Pasal $100(4)^{\prime}$. 
Pasal yang yang menempatkan Pidana Mati sebagai salah satu ancaman hukumannya.

Berikut ini tabel sebaran ketentuan yang mencatumkan ancaman pidana mati dalam RUU KUHP 2019.

\begin{tabular}{cll} 
No & Pasal & Tindak Pidana \\
\hline 1 & 191 & $\begin{array}{l}\text { Makar dengan Maksud } \\
\text { membunuh Presiden \& } \\
\text { Wakil Presiden }\end{array}$ \\
\hline 2 & 192 & $\begin{array}{l}\text { Makar dengan maksud } \\
\text { agar sebagian atau seluruh } \\
\text { wilayah negara Indonesia } \\
\text { memisahkan diri atau } \\
\text { bergabung dengan negara } \\
\text { asing }\end{array}$ \\
\hline 3 & 212 ayat (3) & $\begin{array}{l}\text { Pengkhianatan dalam } \\
\text { Perang }\end{array}$ \\
\hline 4 & 215 & $\begin{array}{l}\text { Pengkhianatan terhadap } \\
\text { negara sekutu dalam } \\
\text { perang gabungan }\end{array}$ \\
\hline 5 & 465 & Pembunuhan berencana \\
\hline 6 & 594 ayat (2) & Bajak Udara \\
\hline 7 & 598 & Tindak Pidana HAM Berat \\
\hline 8 & 599 ayat (1) & Tindak Pidana HAM Berat \\
\hline 9 & 600 & Tindak Pidana Terorisme \\
\hline 10 & 613 ayat (2) & \begin{tabular}{l} 
Tindak Pidana Narkotika \\
\hline
\end{tabular}
\end{tabular}

\section{Analisis Ancaman Pidana Mati dari Perspektif nilai-nilai Pancasila}

Pancasila yang merupakan pandangan hidup bangsa dan dasar negara, digali dan ditemukan dari nilai-nilai yang hidup dan berkembang di dalam masyarakat Indonesia. Sehingg memposisikan pancasila sebagai suatu ideologi yaitu cara pandang terhadap negara. ${ }^{36}$ Oleh karena itu, analisis ancaman pidana mati terhadap tindak pidana ditinjauan dari nilainilai pancasila.

Pertama Kebijakan Moderasi Pidana Mati dalam RUU KUHP akan dianalisis dari nilai-nilai yang terkandung dalam Sila

${ }^{36}$ Hariyanto Hariyanto, 'Pembangunan Hukum Nasional Berdasarkan Nilai-Nilai Pancasila', Volksgeist: Jurnal Ilmu Hukum Dan Konstitusi 1, no. 1 (7 June 2018): 53-63, https://doi.org/10.24090/volksgeist.v1i1.1731.
Pertama, Ketuhanan Yang Maha Esa. Menurut Soekarno kepercayaan kepada Tuhan Yang Maha Esa merupakan Leitstar yang utama, yang menjadikan bangsa kita sebagai bangsa yang mengejar kebajikan dan kebaikan oleh karenanya elemen kepercayaan kepada Tuhan Yang Maha Esa adalah elemen yang paling utama yang menjiwai dan meliputi sila-sila lainnya ${ }^{37}$.

Pemahaman Soekarno sejalan dengan kepercayaan masyarakat Indonesia. Masyarakat Indonesia merupakan masyarakat adat yang pola pikirnya selalu diliputi oleh paham magis religious. Menurut kepercayaan tradisional Indonesia, tiap-tiap masyarakat diliputi oleh kekuatan gaib, yang harus dipelihara supaya masyarakat itu tetap bahagia. Tugas persekutuan masyarakat adalah memelihara keseimbangan lahir dan batin di lingkungan hidupnya (levensmiliue) ${ }^{38}$.

Dengan percaya adanya Tuhan Yang Maha Esa maka menuntun seseorang untuk selalu berbuat baik dan selalu bertanggungjawab sebab pada akhirnya semuanya akan dimintai pertanggungjawabannya di akhirat kelak oleh Tuhan Yang Maha Esa. Kepercayaan kepada Tuhan Yang Maha Esa tersebut sebagaimana ternyata dalam agama-agama yang ada.

Sekalipun ada perbedaan-perbedaan dalam soal keimanan namun dapat pula di tarik titiktitik persamaannya yaitu kepercayaan adanya Tuhan Yang Esa, hari kiamat dan pembalasan. Semua agama yang ada di Indonesia mengajarkan kebajikan. Yang melakukan kebajikan diiming-imingi surga dan yang melakukan kejahatan diancam neraka. Semua agama mengajarkan kaidah-kaidah. Tujuan dari kaidah-kaidah agama adalah agar menjadikan manusia ini bahagia baik di dunia maupun di akhirat.

${ }^{37}$ Soekarno, 'Pantja Sila Sebagai Dasar Negara, Departemen Penerangan RI 1959.', 45.

38 Soepomo, Bab-Bab Tentang Hukum Adat (Pradnya Paramita, 1993), 68-69. 
Dalam konteks kehidupan bernegara kaidah agama juga merupakan salah satu sumber hukum yang ada. Norma agama merupakan sumber penting bagi terbentuknya nilai dan norma etika yang ada dimasyarakat, sementara itu nilai dan norma etika masyarakat menjadi sumber proses terbentuknya norma hukum yang dikukuhkan negara ${ }^{39}$. Dari kaidah-kaidah agama yang ada terdapat ancaman pidana mati bagi kejahatan-kejahatan tertentu.

Hukuman mati menurut hukum Islam diterapkan untuk kasus-kasus tertentu seperti pembunuhan berencana, perzinahan bagi yang sudah nikah, perampokan dengan kekerasan yang mengakibatkan kematian, pemberontakan dan murtad $^{40}$. Sebagaimana yang terkandung dalam Q.S Al-Baqarah ayat 178, Q.S. Albaqarah ayat 179, Q.S. Al-Maidah ayat 33 dan didukung beberapa hadits yang mengatur dan menjelaskan tentang pidana mati.

Pidana mati menurut Etika Kristen dibolehkan sepanjang untuk kejahatan-kejahatan yang besar dan dilakukan oleh negara. Dalam pandangan Kristen hukuman mati harus dilihat sebagai tugas dan tanggungjawab yang diberikan tuhan kepada negara dalam menegakan hukum dan keadilan ${ }^{41}$. Hukuam mati tidak bertentangan dengan Al Kitab. Dalam Al Kitab banyak ayat-ayat yang mengatur tentang hukuman mati. Dalam Al Kitab ada beberapa pengaturan tentang pidana matu, seperti dalam Kitab Kejadian 9:6:"Siapa yang menumphakan darah manusia,darahnya akan tertumpah oleh manusia,.”., Kitab Keluaran 21:12: “siapa yang memukul seseorang, sehingga mati, pastilah ia

39 Jimly Asshidiqie, Pengantar Ilmu Hukum Tatanegara Jilid I (Sekretariat Jenderal dan Kepaniteraan Mahkamah Konstitusi RI, 2006).

${ }^{40}$ Muhamad Taqiyudin, 'Pidana Mati Dalam Perspektif Al-Qur'an (Bagian Abstrak)' (Jakarta, Program Studi Ilmu Al-Qur'an Dan Tafsir Program Pascasarjana Institut PTIQ, 2021).

${ }^{41}$ Tonahati Harefa, 'Kajian Etika Kristen Terhadap Hukuman Mati' (Sekolah Tinggi Teologi Amanat Agung Jakarta, 2017). dihukum mati.”. Ajaran Hukuman mati juga dikenal dalam Agama Hindu sebagaimana terdapat dalam Kitab Kantaka Sodhana ${ }^{42}$.

Dari penjelasan tersebut jelas bahwa Pidana Mati mendapatkan pembenarannya dalam ajaran-ajaran agama yang ada di Indonesia. Kejahatan-kejatahan di Indonesia sendiri yang diancam hukuman mati adalah kejahatan-kejahatan yang mengancam kehidupan dan juga menurut pemahaman masyarakat adat menyebabakan tergangungnya keseimbangan kosmos seperti delik makar, pembunuhan berencana, pengkhianatan dalam perang, terorisme, kejahatan penerbangan, kejahatan HAM, korupsi dalam masa darurat, dan lain-lain. Penjelasan yang demikian sangat beralasan jika pidana mati dijatuhkan adalah berfungsi memulihkan keseimbangan seperti semula. Sehingga dapat disimpulkan bahwa pidana mati tidak bertentangan dengan sila Ketuhanan Yang Maha Esa.

Kedua Pidana Mati dari perspektif sila Kemanusiaan yang adil dan beradab. Kemanusiaan adalah jiwa yang merasakan bahwa martabat manusia lebih tinggi dari binatang ${ }^{43}$. Manusia memiliki potensi pikir, rasa, karsa dan cipta. Dengan akal budinya manusia menjadi berkebudayaan. Dengan budi nuraninya manusia menyadari nilai-nilai dan norma-norma.

Kata adil mengandung arti bahwa segala tindakan didasarkan pada nilai-nilai atau ukuran-ukuran obyektif bukan subyektif yang sewenang-wenang. Beradab berasal dari kata adab yang berarti budaya. Jadi beradab berarti berbudaya. Ini mengandung arti bahwa sikap hidup, keputusan, dan tindakan selalu berdasarkan nilai-nilai budaya, terutama norma sosial dan kesusilaan (moral). Jadi kemanusiaan

${ }^{42}$ I Nyoman Alit Putrawan, I Gusti Ngurah Sudiana, and I Nyoman Sirta, 'Paradara Dalam Delik Kesusilaan Di Kota Denpasar Perspektif Hukum Hindu'.

${ }^{43}$ Soekarno, 'Pantja Sila Sebagai Dasar Negara, Departemen Penerangan RI 1959.', 57. 
yang adil dan beradab adalah kesadaran sikap dan perbuatan manusia yang didasarkan kepada potensi budi nurani manusia dalam hubungan norma-norma dan kebudayaan umumnya, baik terhadap diri pribadi, sesama manusia maupun terhadap alam dan hewan.

Jika kita analisis ketentuan-ketentuan yang mencantumkan ancaman Pidana Mati dalam RUU KUHP seperti Pasal 191 (makar), 192 (makar), 212 ayat (3) (pengkhianatan perang), 215 (pengkhianatan terhadap sekutu), 465 (pembunuhan berencana), 594 ayat (2) (bajak udara), 598 (pelanggaran HAM), 599 (pelanggaran HAM), 600 (terorisme) dan 613 (Kajahanatn Narkotika) semuanya adalah kejahatan yang serius dan berat sehingga tepat jika diancam dengan Pidana Mati.

Ancaman Pidana Mati sebagaimana tercantum dalam pasal-pasal tersebut menurut saya tidak bertentangan dengan Sila Kemanusiaan Yang Adil dan Beradab. Ancaman Hukuman Mati yang dicantumkan tersebut sudah proporsional apabila dihubungkan dengan tujuan dari pemidanaan sendiri. Tujuan pemidanaan yang terdapat dalam RUU KUHP menganut teori gabungan yaitu menyeimbangkan tujuan pembalasan dan juga mempertahankan ketertiban masyarakat.

Sebagaimana dapat dilihat dalam Pasal 51 RUU KUHP tujuan pertama dari pemidanaan adalah mencegah dilakukannya tindak pidana dengan menegakan norma hukum demi melindungi dan mengayomi masyarakat. Ancaman Pidana Mati sebagaimana disebutkan dalam pasal-pasal tersebut jelas bertujuan untuk menimbulkan efek jera dimana orang lain akan takut melakukan hal serupa jika tidak ingin dihukum mati.

Dilihat dari segi masyarakat ini dapat dikategorikan sebagai bentuk perlindungan dan pengayoman. Jika dilihat dari sudut pelaku tindak pidana ancaman hukuman ini merupakan bentuk pembalasan yang setimpal. Pembalasan yang setimpal ini merupakan bentuk dari penyelesaian konflik, di sisi lain Pidana Mati merupakan sarana terkhir. Sehingga pelaksanaanya dapat ditunda terlebih dahulu melalui masa percobaan dimana apabila dalam masa percobaan pelau menujukan perubahan yang signifikan maka hukumannya dapat dirubah menjadi hukuman seumur hidup.

Ketiga Pidana Mati dari perspektif Sila Persatuan Indonesia. Persatuan Indonesia adalah sila ketiga dari Pancasila. Menurut Soekarno sila ini adalah sila kebangsaan. Kebangsaan adalah soal yang terkait dengan persoalan bangsa. Bangsa adalah terjemahan dari nation. Menurut Ernest Renan bangsa adalah satu jiwa atau Bahasa Prancisnya Une nation est un ame ${ }^{44}$.

Dalam kesempatan lain Ernest Renan berkata bahwa bangsa adalah satu solidaritet yang besar atau Une nation est un grand solidariteit. Lalu apa yang menjadi pengikat menjadi satu jiwa tersebut. Yang menjadi pengikat satu jiwa tersebut adalah Le desir detre esemble atau kehendak untuk hidup bersama. Sementara itu menurut Otto Bauer bangsa adalah "eine aus Schicksalgemenschaft erwachsene Chracter-gemeinschaft" atau terjemahannya: bangsa adalah satu persamaan, satu persatuan karakter. Karakter ini lahir, tumbuh, dan terjadi karena adanya persatuan pengalaman. Dari dua pendapat Sarjana tersebut kemudian Soekarno menambah satu lagi unsur yaitu berdiam dalam satu wilayah geopolitik yang satu $^{45}$. Sehingga menurut Soekarno bangsa itu adalah sekumpulan manusia yang mempunyai kehendak hidup bersama dan mempunyai karakteristik yang sama dan menempati suatu wilayah geolpolitik yang nyata satu persatuan, satu kesatuan yang satu unit.

Rasa kebangsaan ini lahir karena adanya tuntutan yang tidak dapat dihindari. Tuntutan

\footnotetext{
${ }^{44}$ Soekarno, 65.

${ }^{45}$ Soekarno, 65.
} 
ini lahir karena adanya keadaan-keadaan yang menjadikan kita bersatu dalam satu wadah yang tunggal dan tidak terbagi-bagi. Kalau hanya bagian-bagian tertentu maka bukan bangsa. Oleh karenanya jika di suatu Negara didasarkan pada rasa kebangsaan yang tinggi, maka Negara menjadi kuat karena bersatu padu yang didasarkan pada kehendak untuk hidup bersama karena mempunyai kesamaan karakter, watak yang disebabakan suatu pengalaman sejarah.

Selain itu, perlu dipahami bahwa paham kebangsaan ini juga tidak bisa dilepaskan dan dipisahkan dari sila lain yaitu kemanusiaan yang dijelaskan dalam analisis pidana mati dari sila kelima. Karena kalau tidak dibarengi dengan sila kemanusiaan maka rasa kebangsaan ini menjadi chauvinisme seperti terjadi di Jerman pada zaman Hitler.

Selanjutnya, eksistensi Pidana Mati jika dikaitkan dengan paham kebangsaan ini. Jika dilihat ancaman pidana mati semua itu diancamkan kepada pelaku kejahatan-kejahatan yang serius yang salah satunya merongrong rasa kebangsaan atau persatuan ini seperti makar, terorisme, korupsi disaat Negara dalam keadaan darurat, membantu atau melindungi musuh Negara, pengkhianatan perang, dan lain-lain. Oleh karenanaya menurut penulis dipertahankannya pidana mati dalam sistem hukum di Indonesia tidaklah bertentangan dengan sila kebangsaan.

Pidana mati merupakan balasan yang setimpal dan merupakan bentuk penyelesaian konflik. Pidana mati merupakan sangat dibutuhkan sebagai bentuk perlindungan dan pengayoman terhadap masyarakat dalam menjaga persatuan di Indonesia. Jika kejatahankejahatan sebagaimana disebutkan di atas tidak diancam pidana mati dikahwatirkan mengamcam persatuan Indonesia. Ancaman Pidana Mati sebagaimana dicantumkan dalam Pasal-pasal tersebut jelas mempunyai dasar pembenar dari Sila Persatuan Indonesia.
Sila keempat. Pidana mati dari paham demokrasi atau Kedaualatan Rakyat. Kita mempunyai kepercayaan hidup bernegara harus berdasar kedaulatan rakyat. Karena bernegara sejatinya adalah kesepakatan bersama orangorang yang ada dalam suatu Negara dalam menjalankan kehidupan bersama. Kesepakatan tersebut kemudian dituangkan dalam sebuah dokumen yang dikenal dengan konstitusi, yang mana konstitusi merupakan hukum dasar bagi penyelenggaran kehidupan bernegara.

Pemerintah yang menjalanakan kekuasaan Negara hendaknya berpegang teguh pada konstitusi dan undang-undang sebagai perwujudan kesepakatan tertulis antar warganegara. Konstitusi sejatinya adalah kesepakatan yang isinya berupa rambu-rambu bagi pemegang kekuasaan dalam menjalankan kekuasaanya sekaligus juga mengatur tentang dasar-dasar dalam hidup bernegara.

Soekarno berkata: Dalam cara pemikiran kita demokrasi itu bukan alat saja untuk mencapai tujuan tetapi juga suatu "geloof", suatu kepercayaan dalam usaha mencapai bentuk masyarakat sebagai yang kita cita-citakan ${ }^{46}$. Oleh karena itu kita mempunyai corak sendiri yang berbeda dengan bangsa-bangsa lain. Kita juga tidak perlu identik dengan demokrasi seperti Negara-negara lain.

Sejalan dengan Soekarno, Adnan Buyung Nasutian berpendapat sama. Demokrasi menurutnya bukan hanya cara, alat atau proses tetapi nilai-nilai atau norma-norma yang harus menjiwai dan mencerminkan keseluruhan proses kehidupan kita bermasyarakat, berbangsa dan bernegara. Demokrasi bukan hanya kriteria di dalam merumuskan proses untuk mencapai tujuan, melainkan tujuan itu sendiri pun haruslah mengandung nilai-nilai atau norma-norma demokrasi ${ }^{47}$.

${ }^{46}$ Soekarno, 'Pantja Sila Sebagai Dasar Negara, Departemen Penerangan RI 1959.'

47 Adnan Buyung Nasution, Demokrasi Konstitusional (Kompas, Kompas), 3-5. 
Demokrasi itu memiliki roh yang tidak lain adalah hak-hak dasar atau asasi manusia yang merupakan kriteria obyektif dan universal untuk menilai kemajuan peradaban sesuatu bangsa tidak terkecuali bangsa Indonesia. Vox populi vox dei sering diartikan jika mayoritas berkehendak maka jadilah. Padahal majority rule hanyalah salah satu aturan main dalam demokrasi. Ia bukan fondasi dari demokrasi sendiri. Demokrasi bukan soal prosedur saja. Demokrasi harus memiliki substansi yaitu prinsip-prinsip pokok yang harus ditegakan. Demokrasi juga harus berdasarkan prinsip konstitusionlaisme yang bertujuan membatasi kesewenang-wenangan kekuasaaan ${ }^{48}$.

Kelompok fundamentalis agama sering membajak demokrasi. Demokrai yang hanya dipahami dengan demokrasi prosedural akan dibajak oleh kelompok ini. Demokrasi harus didasarkan prinsip konstitusionalisme. Prinsip ini harus ditegakan dengan proses hukum yang adil, pemisahan kekuasaan, check and balances, serta menghormati HAM. Dalam perkembangannya juga judicial review atau pengaduan kontitusional ${ }^{49}$.

Dari analisis tersebut jelas bahwa pidana mati sangat tepat diancamkan tehadap kejahatan-kejahatan yang mengancam demokrasi seperti makar, kejahatan terorisme, korupsi, tindak pidana HAM berat, bajak udara, menyebabkan huru hara dikalangan militer dan lain-lain. Sehingga menurut pendapat penulis bahwa pidana mati ini justru untuk menegakan norma-norma yang dikembangkan dari nilainilai yang terkandung dalam sila kerakyatan yang dipimpin oleh hikmat kebijaksanaan dalam permusyawarata/ perwakilan.

Sila Kelima. Keadilan Sosial. Dalam sila ini ada amanat penderitaan rakyat, ada amanat para pejuang yang telah mendahului kita agar kita yang masih hidup hendaknya mengisi

\footnotetext{
${ }^{48}$ Adnan Buyung Nasution, 12.

${ }^{49}$ Adnan Buyung Nasution, 140.
}

kemerdekaan ini untuk menciptakan kemajuan bersama untuk mewujudkan masyarakat yang adil dan makmur.

Terwujudnya keadilan harus didasarkan atas keadilan, ketertiban dan keteraturan, dimana setiap orang mendapatkan kesempatan membangun kehiduan yang layak sehingga kesejahteraan umum. Perwujudan keadilan sosial menghendaki adanya pemerataan sumber daya agar kelompok yang lemah dapat dientaskan dari kemiskinan agar kesenjanagn sosial dapat dikurangi ${ }^{50}$.

Keadilan sosial harus diterapkan dalam bidang kehidupan sosial ekonomi dan politik tanpa diskriminasi. Akibatnya, semua kegiatan pribadi yang bertentangan dengan prinsip dasar ini, seperti monopoli, nepotisme, konspirasi seharusnya tidak memiliki ruang dalam pembangunan. Karena realisasi prinsip ini harus menekankan martabat yang sama dari pribadi manusia. Tidak boleh ada ekploitasi antar manusia. Keadilan sosial berarti keadilan yang berlaku dalam masyarakat di segala bidang kehiduan baik materiil maupun spiritual. Setiap orang mendapat perlakuan yang adil dalam bidang hukum, politik, ekonomi, dan kebudayaan. Sila keadilan sosial adalah tujuan dari empat sila yang mendahuluinya ${ }^{51}$.

Untuk menciptakan masyarakat yang adil dan makmur maka kita harus berusaha sekuat tenaga untuk meningkatkan kapasitas pribadi, meningkatkan sumber daya manusia. Kita semua harus berani mengambil pelajaranpelajaran dari bangsa-bangsa lain dengan tanpa prasangka. Pokokya semua yang kita anggap baik walaupuan darimana datangnya harus kita ambil.

${ }^{50}$ Purwanto, 'Perwujudan Keadilan Dan Keadilan Sosial Dalam Negara Hukum Indonesia: Perjuangan Yang Tidak Mudah Dioperasionalkan' Vol I, No. I: 2017, Jurnal Hukum Media Bhakti (n.d.).

51 Yuni Herawatie, 'Konsep Keadilan Social Dalam Bingkai Sila Kelima Pancasila.', Jurnal UPNYK Vol 18 No. (1 January 2014). 
Dengan demikian segala gangguan, segala perbuatan yang ditujukan untuk mengacaukan dan tidak tercapainya nilai-nilai dalam sila ke lima tersebut dapat dibenarkan apabila dikenakan sanksi termasuk sanksi pidana mati terhadap tindak pidana-tindak pidana seperti makar kepada presiden, makar separitisme, korupsi, tindak pidana penyalahgunaan narkotika, terorisme, tindak pidana terhadap kemananan negara, pengkhianatan perang, membuat huru hara dikalangan militer dan lain-lain.

\section{PENUTUP}

Dari pembahasan diatas dapat diambil kesimpulan bahwa pidana mati tidak bertentangan dengan nilai-nilai Pancasila karena pidana mati justru diadakan untuk tujuan menegakan norma-norma yang dikembangkan dari sila-sila pancasila. Dasar kebijakannya guna menyalurkan hasrat balas dendam masyarakat melalui jalur hukum, menghindari extra legal execution, mencari keadilan, dan menimbulkan efek jera dan sebagai upaya perlindungan terhadap "hak hidup" dari banyak orang. Semua itu sejalan dengan nilai-nilai Pancasila

\section{DAFTAR PUSTAKA}

A. Hamid S. Attamimi. Pancasila Cita Hukum Dalam Kehidupan Hukum Bangsa Indonesia, Dalam Moerdiono Dkk, Pancasila Sebagai Ideologi Dalam Berbagai Bidang Kehidupan Bermasyarakat, Berbangsa Dan Bernegara, Disunting Oleh Oetojo Oesman Dan Alfian. BP-7 Pusat, 1992.

A. S. Attamimi,. Gesetz Gebung Swissens Chaft Sebagai Salah Satu Upaya Menanggulangi Hutan Belantara Peraturan PerundangUndangan. Depok: Badan Penerbit FH UI, 2021.
Adnan Buyung Nasution. Demokrasi Konstitusional. Kompas, Kompas.

Ajie Ramdan, Rully Herdita Ramadhani, and Mei Susanto. 'Kebijakan Pidana Mati Dalam RKUHP Ditinjau Dari Aspek Politik Hukum Dan HAM'. Arena Hukum 11 Nomor 3 (Desember 2018).

Andi Hamzah. Pidana Mati Di Indonesia Di Masa Lalu, Kini Dan Di Masa Depan. Ghalia Indoesia, 1985.

Ayub Torry Satriyo Kusumo. 'Hukuman Mati Ditinjau Dari Perspektif Hukum Dan Hak Asasi Manusia Internasional', n.d. Koleski Pusat Dokumentasi ELSAM.

Bambang Poernomo. Asas-Asas Hukum Pidana. Jakarta: Ghalia Indonesia, 1993.

Benhard Ruben Fritz Sumigar,. 'Pelangaran Berat HAM Dalam RUU KUHP: Tinjauan Dari Hukum Internasional' Vol 11 No. 2 November 2020. (n.d.).

Darji Darmodiharjo, and dkk. Santiaji Pancasila.

Surabaya: Usaha Nasional, 1991.

Draff Naskah Akademik RUU KUHP Pasal 100 (4)', n.d.

Franz Magnis Suseno. Etika Politik PrinsipaPrinsip Moral Dasar Kenegaraan Modern. Jakarta: Gramedia Pustaka Utama, 2001.

Hariyanto, Hariyanto. 'Pembangunan Hukum Nasional Berdasarkan Nilai-Nilai Pancasila'. Volksgeist: Jurnal Ilmu Hukum Dan Konstitusi 1, no. 1 (7 June 2018): 53-63. https://doi.org/10.24090/ volksgeist.v1i1.1731.

I Nyoman Alit Putrawan, I Gusti Ngurah Sudiana, and I Nyoman Sirta. 'Paradara Dalam Delik Kesusilaan Di Kota Denpasar Perspektif Hukum Hindu'. Jurnal Penelitian Agama Hindu Volume 3 Nomer 1 tahun 2019 (n.d.).

JE Sahetapy. 'Pidana Mati Dalam Negara Pancasila, Citra Aditya Bandung 2007 Hal 73; Lihat Juga Lidya Suryani 
Widayati, Pidana Mati Dalam RUU KUHP: Perlukan Diatur Sebagai Pidana Yang Bersifat Khusus? Jurnal Negara Hukum: Vol. 7 No. 2 November 2016. Hal 168', n.d.

Jimly Asshidiqie. Pengantar Ilmu Hukum

Tatanegara Jilid I. Sekretariat Jenderal dan Kepaniteraan Mahkamah Konstitusi RI, 2006.

Lidya Suryani Widayati,. 'Pidana Mati Dalam RUU KUHP: Perlukan Diatur Sebagai Pidana Yang Bersifat Khusus? Jurnal Negara Hukum' Vol. 7 No. 2 November 2016. (n.d.).

Moh Mahfud MD. Membangun Politik Hukum, Menegakkan Konstitusi. Jakarta: LP3ES, 2006.

Muhamad Taqiyudin. 'Pidana Mati Dalam Perspektif Al-Qur'an (Bagian Abstrak)'. Program Studi Ilmu Al-Qur'an Dan Tafsir Program Pascasarjana Institut PTIQ, 2021.

Padmo wahyono. Indonesia Berdasar Atas Hukum. Ghalia Indonesia, n.d.

Peter Mahmud Marzuki. Penelitian Hukum. Jakarta: Kencana Prenanda Media Group, 2005.

Purwanto. 'Perwujudan Keadilan Dan Keadilan Sosial Dalam Negara Hukum Indonesia: Perjuangan Yang Tidak Mudah Dioperasionalkan' Vol I, No. I: 2017, Jurnal Hukum Media Bhakti (n.d.).
Roby Anugerah, and raja Desril. 'Kebijakan Formulasi Pidana Mati Dalam Pembaharuan Hukum Pidana Indonesia, Jurnal Pembangunan Hukum Indonesia' Jurnal Pembangunan Hukum Indonesia Volume 3 No 1 tahun 2021 (n.d.): 80-95.

Saharuddin Daming. 'Konfigurasi Pertarungan Abolisinisme Versus Retensionisme Dalam Diskursus Keberadaan Lembaga Pidana Mati Di Tingkat Global Dan Nasional', n.d.

Soehino. Politik Hukum Di Indonesia. Yogyakarta: Penerbit BPFE, 2010.

Soekarno. 'Pantja Sila Sebagai Dasar Negara, Departemen Penerangan RI 1959.', n.d.

Soepomo. Bab-Bab Tentang Hukum Adat. Pradnya Paramita, 1993.

Tia Ludiana. 'Eksistensi Pidana Mati Dalam Pembaharuan Hukum Pidana (Kajian Terhadap Pidana Mati Dalam RUU KUHP)'. Jurnal Litigasi (e-Journal) Vol. 22 (1) (April 2020).

Tim Institute For Criminal Justice Reform (ICJR). Politik Kebijakan Hukuman Mati Di Indonesia Dari Masa Ke Masa. Jakarta, n.d.

Tonahati Harefa. 'Kajian Etika Kristen Terhadap Hukuman Mati'. 2017.

Yuni Herawatie. 'Konsep Keadilan Social Dalam Bingkai Sila Kelima Pancasila.' Jurnal UPNYK Vol 18 No. (1 January 2014). 